\title{
PENERAPAN RELAKSASI OTOT PROGRESIF TERHADAP ANSIETAS PADA ASUHAN KEPERAWATAN PASIEN DIABETES MELITUS
}

\author{
Implementation of Progressive Muscle Relaxation Against Ansietas in Nursing Care \\ for Diabetes Mellitus Patients
}

\author{
Dafrosia Darmi Manggasa*, Ni Made Ridla Nilasanti, Nirva Rantesigi, Ulfa Sufyaningsi \\ Poltekkes Kemenkes Palu \\ *Email korespondensi: dafrosiamanggasa@yahoo.com,
}

\begin{abstract}
ABSTRAK
Pendahuluan: Diabetes Mellitus (DM) diartikan sebagai penyakit metabolisme yang termasuk dalam kelompok gula darah yang melebihi batas normal atau hiperglikemia (lebih dari $120 \mathrm{mg} / \mathrm{dl}$ ), karena itu DM sering disebut juga dengan penyakit gula. Penyakit diabetes melitus adalah masalah kesehatan yang besar. Hal ini dikarenakan adanya peningkatan jumlah penderita diabetes dari tahun ke tahun. Berdasarkan faktor resiko DM terbagi menjadi 2 tipe yaitu: tipe I dan tipe II. Individu yang menderita DM tipe I memerlukan suplai insulin dari luar (eksogen insulin). sedangkan individu dengan DM tipe II resisten terhadap insulin. Tujuan: Untuk mengetahui penerapan relaksasi otot progresif terhadap tingkat ansietas pada asuhan keperawatan dengan kasus diabetes melitus di ruangan interna RSUD Poso. Metode Penelitian: Yaitu dengan menggunakan metode pemberian tindakan Relaksasi Otot Progresif Terhadap Tingkat Ansietas Pada Asuhan Keperawatan Dengan Kasus Diabetes Melitus. Hasil Penelitian: Setelah dilakukan implementasi selama 4 hari 2 kali penerapan relaksasi otot progresif, tingkat ansietas pasien tampak berkurang. Setelah dilakukan tindakan Relaksasi Otot Progresif selama 4 hari diharapkan tingkat ansietas pasien dapat berkurang dengan kriteria: tingkat ansietas hanya ringan, dan selalu menunjukkan pengendalian diri terhadap ansietas. Saran: diharapkan perawat yang ada di rumah sakit dapat memberikan penerapan relaksasi otot progresif secara optimal kepada pasien yang mengalami ansietas pada kasus diabetes melitus.
\end{abstract}

Kata kunci: Ansietas; Diabetes Melitus; Relaksasi Otot Progresif;

\begin{abstract}
Introduction: Diabetes Mellitus (DM) is defined as a metabolic disease that is included in the blood sugar group that exceeds the normal limit or hyperglycemia (more than $120 \mathrm{mg} / \mathrm{dl}$ ), therefore DM is often referred to as diabetes. diabetes mellitus is a big health problem. This is due to an increase in the number of diabetics from year to year. Based on the risk factors for DM, it is divided into 2 types, namely: type I and type II. Individuals suffering from type I diabetes need an external insulin supply (exogenous insulin). whereas individuals with type II DM are insulin resistant. Useful aim: This is to determine the application of progressive muscle relaxation to the level of anxiety in nursing care with diabetes mellitus cases in the internal room of RSUD Poso. Research Methods: Namely by using the method of giving action Progressive Muscle Relaxation on Anxiety Levels in Nursing Care with Diabetes Mellitus Cases. Results: After 4 days of implementation for 2 times progressive muscle relaxation, the patient's anxiety level appeared to be reduced. After 4 days of Progressive Muscle Relaxation, it is expected that the patient's level of anxiety can be reduced by the following criteria: the level of anxiety is only mild, and always shows self-control against anxiety. Suggestion: It is hoped that the nurses in the hospital can provide the optimal application of progressive muscle relaxation to patients who experience anxiety in cases of diabetes mellitus.
\end{abstract}

Keywords : Anxiety; Diabetes Melitus; Progressive Muscle Relaxation;

https://doi.org/10.33860/mnj.v1i2.267

(C) 2020 by the authors. Submitted for possible open access publication under the terms and conditions of the Creative Commons Attribution (CC BY SA) license (https://creativecommons.org/licenses/by-sa/4.0/). 


\section{PENDAHULUAN}

Diabetes Mellitus (DM) diartikan sebagai penyakit metabolisme yang termasuk dalam kelompok gula darah yang melebihi batas normal atau hiperglikemia (lebih dari $120 \mathrm{mg} / \mathrm{dl}$ ). Menurut International Diabetes Federation (IDF) menyebutkan bahwa penyakit diabetes melitus adalah masalah kesehatan yang besar. Hal ini dikarenakan adanya peningkatan jumlah penderita diabetes dari tahun ke tahun. ${ }^{2}$

Pada tahun 2015 Indonesia berada diperingkat ke-7 untuk penderita DM didunia dan diperkirakan akan naik ke peringkat enam pada tahun $2035 .^{2}$ Data dari Profil Kesehatan Sulawesi Tengah tahun 2015 jumlah penderita DM yang tercatat berjumlah 5.433 kasus. Data dari Kabupaten Poso 2015 jumlah penderita DM sebanyak 350 kasus, tahun 2016 sebanyak 2.390 kasus, dan 2017 meningkat menjadi 3.168 kasus. ${ }^{3}$ Penyakit diabetes melitus disebabkan oleh banyak faktor, diantaranya adalah faktor keturunan, obesitas, gaya hidup, pola makan, obat-obatan yang mempengaruhi kadar glukosa darah, kurangnya aktivitas fisik, kehamilan, perokok dan stress. ${ }^{4}$

Gejala gejala yang timbul pada kasus diabetes mellitus seperti kulit terasa panas, kelelahan, pandangan mulai kabur, poliuri dan polidipsi. Karena glukosa hilang bersama urine, maka pasien mengalami kalori negatif dan berat badan berkurang, polifagi mungkin akan timbul sebagai akibat kehilangan kalori, lelah dan mengantuk. ${ }^{5}$

Terbatasnya informasi mengenai penyakit diabetes mellitus, para diabetes di tahun-tahun awal akan mengalami ansietas yang didefinisikan sebagai kebingungan yang kemudian dicirikan dengan perasaan tidak yakin, putus asa, perasaan tertekan, bimbang dan gugup. ${ }^{6}$ Ansietas adalah kebingungan atau kehawatiran ketidak berdayaan dan ketidaknyamanan pada sesuatu yang terjadi dengan penyebab tidak jelas dan dihubungkan dengan perasaan tidak menentu dan tidak berdaya. ${ }^{7}$ Penanganan ansietas ada beberapa macam cara salah satunya teknik relaksasi otot progresif, dimana klien secara sistematis membuat kelompok-kelompok otot utama di tubuh klien menjadi rileks satu demi satu. ${ }^{8}$

Relaksasi otot progresif merupakan salah satu teknik untuk mengurangi ketegangan otot dengan proses yang simpel dan sistematis dalam menegangkan sekelompok otot kemudian merilekskannya kembali yang dimulai dengan otot wajah dan berakhir pada otot kaki. ${ }^{9}$ Terapi relaksasi otot progresif merangsang pengeluaran zat-zat kimia endorphin dan ensephalin serta merangsang signal otak yang menyebabkan otot rileks dan meningkatkan aliran darah ke otak. ${ }^{7}$

Efektifitas dari terapi relaksasi otot progresif telah banyak dibuktikan dengan penelitian seperti pada penelitian yang dilakukan oleh Tobing, Keliat dan Wardhani (2012) yang menunjukkan adanya penurunan ansietas serta peningkatan kemampuan relaksasi dan kemampuan memaknai hidup setelah dilakukan tindakan PMR. Gitanjali dan Sreehari (2014) pasien yang melakukan relaksasi otot progresif secara kontinu selama 3 hari dapat membantu klien menurunkan rasa khawatir dan lebih rileks. ${ }^{10}$

Berasarkan studi pendahuluan di RSUD poso jumlah kasus DM pada tahun 2015 sebanyak 94 kasus, pada tahun 2016 sebanyak 139 kasus, dan pada tahun 2017 mengalami peningkatan sebanyak 185 kasus. Pasien diabetes melitus selalu mengalami rasa cemas atau takut akan penyakit diabetes melitus yang dideritanya. Penanganan diabetes melitus lebih berfokus pada luka diabetes melitus, sedangkan penanganan masalah ansietas masih belum maksimal dilakukan karena pengakjian belum secara holistik. Penanganan akan lebih optimal bila masalah tersebut ditangani secara bersamaan. Tujuan penelitian ini untuk mengetahui penerapan relaksasi otot progresif terhadap tingkat ansietas pada asuhan keperawatan dengan kasus diabetes melitus.

\section{METODE PENELUSURAN}

Penulisan karya ilmiah ini menggunakan metode studi kasus, yaitu analisis penerapan relaksasi otot progresif pada asuhan keperawatan diabetes melitus dengan masalah keperawatan ansietas. Adapun teknik pengumpulan data yang digunakan meliputi wawancara, observasi, catatan individu, atau rekam medik dan perawatan. Data yang telah terkumpul dianalisis untuk melihat masalah keperawatan yang dialami klien serta meninjau keefektifan intervensi yang telah dilakukan untuk menyelesaikan masalah keperawatan pasien.

\section{HASIL PENELITIAN}

Hasil pengkajian didapatkan data: Klien Ny.W, umur 51 tahun, jenis kelamin 
perempuan, status sebagai ibu rumah tangga, agama hindu, alamat Desa Malino, dengan nomor rekam medik 111242. Penanggung jawab Ny. W adalah Tn. K, umur 26 tahun, yang merupakan anak dari klien. Klien masuk RSUD Poso dengan keluhan sesak nafas, pusing dan badan terasa lemah keluhan dirasakan sejak dua hari sebelum masuk rumah sakit. Klien juga mengeluh susah tidur, sering berkemih dan klien mengatakan takut dengan penyakitnya, dada berdebar.

Pemeriksaan fisik Ny.W, didapatkan dari pemeriksan yaitu kesadaran Composmentis, keadaan umum klien tampak lemah, hasil pemeriksaan tanda - tanda vital didapatkan TD: 100/70 mmHg, suhu: 36 c, Nadi : 86 kali/menit dan pernapasan. SPO2 $97 \%$, CRT kurang dari 3 detik, tidak ada sianosis, tidak ada pembesaran jantung. Tidak terdapat gangguan menelan, tidak terpasang NGT, tidak ada keluhan mual muntah, mukosa bibir kering, terdengar bising usus $8 \mathrm{x} /$ menit,terdengar bunyi timpani, tidak ada kesulitan BAB. irama nafas bronchial, kedalaman pernapasan dangkal, terpasang oksigen melalui nasal kanul $5 \mathrm{~L} /$ menit, pasien nampak sesak, tidak ada pernapasan cuping hidung, pergerakan dada sesuai dengan inspirasi dan ekspirasi. Extremitas atas dan bawah berfungsi secara normal, kekuatan otot 5 . Kulit lembab, tidak ada edema, tidak ada lesi, turgor kulit elastis.

Data psikologis klien mengatakan takut dengan penyakit diabetesnya menjadi luka, klien mengatkan tidak paham tentang penyakitnya, klien tampak cemas, klien mengatakan susah tidur, klien mengatakan sering terbangun dari tidur dimalam hari, klien sering bertanya tentang penyakinya, klien juga bertanya apakah penyakitnya masih bisa sembuh, klien nampak gelisah, klien mengeluh lemah.

Berdasarkan hasil pengkajian pada Ny. W didapatkan data klien mengatakan sesak napas, pernapasan dangkal terpasang oksigen 5 L/menit. Berdasarkan data tersebut dapat disimpulkan diagnosa yang muncul yaitu: Ketidakefektifan pola napas. Masalah lain yang muncul yaitu ansietas berhubungan dengan perubahan status kesehatan ditandai dengan Klien mengatakan takut dengan penyakit diabetesnya menjadi luka, klien mengatakan tidak paham tentang penyakitnya, klien mengatakan susah tidur, klien nampak gelisah, klien mengatakan sering berkemih, klien mengatakan dada rasanya berdebar.

\section{PEMBAHASAN}

Asuhan keperawatan memfokuskan pada pemenuhan kebutuhan dasar manusia melalui tahap pengkajian, diagnosa keperawatan, intervensi keperawatan, implementasi dan evaluasi. Penulis akan membahas tentang aplikasi pemberian relaksasi otot progresif terhadap tingkat ansietas pada asuhan keperawatan Ny. W dengan kasus diabetes melitus diruangan interna RSUD Poso.

Dalam pengkajian didapatkan data bahwa klien datang dengan keluhan sesak nafas, sesak nafas ini dikarenakan pasien masuk rumah sakit dengan diangnosa lain yaitu asma bronchial, keluhan sesak merupakan keluhan utama yang sering muncul pada kasus asma bronchial, pusing dan penglihatan tampak kabur, karena sudah terjadi komplikasi sehingga terjadi retinopati yang mengakibatkan pasien DM mengalami gangguan penglihatan, badan terasa lemah, klien tampak gelisah, nadi cepat, sering berkemih. keluhan dirasakan sejak 2 hari sebelum masuk rumah sakit. Berdasarkan data yang didapatkan dari pengkajian pada Ny.W sesuai dengan teori sebelumnya. ${ }^{5}$

Hasil pengkajian didapatkan diagnose keperawatan adalah ansietas berhubungan dengan perubahan status kesehatan ditandai dengan Klien mengatakan takut dengan penyakit diabetesnya menjadi luka, klien mengatakan susah tidur, wajah tampak tegang, klien nampak gelisah, peningkatan denyut nadi, klien mengatakan sering berkemih. Penanganan yang dilakukan adalah dengan teknik relaksasi otot progresif yaitu teknik relaksasi otot dalam yang tidak memerlukan imajinasi atau sugesti. Berdasarkan keyakinan bahwa tubuh manusia berespon pada kecemasan dan kejadian yang merangsang pikiran. Ketika otot - otot sudah dirilekskan maka akan menormalkan kembali fungsi organ tubuh, setelah melakukan relaksasi dapat membantu tubuhnya menjadi rileks. Selain itu juga dengan relaksasi akan membuat individu lebih mampu menghindari reaksi yang berlebihan karena adanya stres, serta mengurangi kecemasan.

Evaluasi keperawatan pada Ny. W yang dirawat di ruangan interna RSUD Poso dilakukan pada hari jumat, sabtu, minggu dan senin untuk diagnosa ansietas didapatkan hasil evaluasi klien terlihat tidak lagi gelisah, klien 
sudah tidak memikirkan tentang penyakitnya, klien mampu mengendalikan tingkat kecemasnya dengan melakukan teknik relaksasi otot progresif secara mandiri, klien mengatakan sudah mulai bisa tidur dengan nyenyak, klien sudah tidak bertanya tentang penyakitnya. Berdasarkan penelitian yang dilakukan oleh Edmund Jacobson terapi keperawatan yang efektif pada ansietas telah terbukti yaitu terapi relaksasi otot progresif (relaxation progressive). Terapi relaksasi otot progresif merangsang pengeluaran zat-zat kimia endorphin dan ensephalin serta merangsang signal otak yang menyebabkan otot rileks dan meningkatkan aliran darah ke otak. ${ }^{7}$ Penelitian tentang relaksasi otot progresif menunjukkan bahwa pasien pasien yang melakukan relaksasi otot progresif secara kontinu selama 3 hari dapat membantu klien menurunkan rasa khawatir dan lebih rileks. ${ }^{11}$

Berdasarkan hasil tindakan dengan menggunakan tekhnik relaksasi otot progresif menunjukan bahwa teknik relaksasi otot progresif mampu menurunkan tingkat ansietas pada kasus diabetes melitus diruangan interna RSUD poso. Tindakan ini dilakukan selama 4 hari dan mendapatkan hasil evaluasi dengan masalah teratasi. dalam penelitian yang dilakukan penulis di RSUD Poso sesuai dengan penelitian yang dilakukan sebelumnya, hanya terdapat perbedaan satu hari untuk mendapatkan evaluasi dengan masalah teratasi, dimana pada penelitian sebelumnya dalam waktu tiga hari peneliti mampu mendapatkan evaluasi dengan masalah teratasi. Sedangkan pada penelitian yang penulis lakukan sekarang, memerlukan waktu 4 hari untuk mendapatkan evaluasi dengan masalah teratasi. Hal ini bisa disebabkan oleh perbedaan tingkat ansietas yang ditangani, penelitian sebelumnya bisa saja melakukan penerapanya pada kasus dengan tingkat kecemasan ringan sehingga dalam 3 hari masalah dapat teratasi

\section{SIMPULAN DAN SARAN}

Pengkajian Ny. W dengan kasus diabetes melitus didapatkan data keluhan berupa pasien mengeluh pusing, pandangan tampak mulai kabur, badan terasa lemah, susah tidur, sesak nafas. sering berkemih, klien tampak gelisah, klien mengatakan takut dengan penyakitnya dan peningkatan denyut nadi. Diagnosa keperawatan yaitu ansietas berhubungan dengan perubahan status Kesehatan. Intervensi keperawatan yang dilakukan untuk diagnosa ansietas adalah Teknik relaksasi otot progresif. Implementasi yang dilakukan yaitu memberikan tekhnik relaksasi otot progresif selama 4 hari untuk mengatasi masalah ansietas. Setelah dilakukan tindakan keperawatan selama 4 hari masalah ansietas dapat teratasi. Diharapkan perawat yang ada di rumah sakit dapat memberikan relaksasi otot progresif secara optimal kepada pasien diabetes melitus dengan masalah ansietas.

\section{DAFTAR PUSTAKA}

1. Maulana M. Mengenal Diabetes Melitus Panduan Praktis Menangani Penyakit kencing Manis. Jakarta: Katahati; 2015.

2. American Diabetes Association. Standards of Medical Care in Diabetes 2017. Volume 40. USA: ADA; 2017.

3. Dinas Kesehatan Sulawesi Tengah. Prevalensi Diabetes Melitus di Sulawesi Tengah [Internet]. 2018. Available from: https://dinkes.sultengprov.go.id/

4. Muflihatin SK. Hubungan Tingkat Stres Dengan Kadar Glukosa Darah Pasien DM Tipe 2 Di RSUD Abdul Wahab Syahranie Samarinda. Samarinda; 2015.

5. Tarwoto, Wartonah. Kebutuhan Dasar Manusia dan Proses Keperawatan. 4th ed. Jakarta: Trans Info Medika; 2015.

6. Novitasari R. Diabetes Melitus Medical Book. Yogyakarta: Nuha Medika; 2012.

7. Stuart G. Principles and Practice of Psychiatric Nursing. 7th ed. Philadephia: Mosby; 2013.

8. Conrad A, Roth W. Muscle relaxation therapy for anxiety disorders: It works but how? J Anxiety Disord. 2012;21:243-64.

9. Marks TI. Master Your Sleep, Proven Methode Simplied. USA: Bascom Hils Publish Group; 2011.

10. Tobing D., Keliat BA, Wardani I. Pengaruh Progressive Muscle Relaxation dan Logoterapi Terhadap Ansietas Dan Depresi, Kemampuan Relaksasi dan Kemampuan Memaknai Hidup Klien Kanker di RS Kanker Dharmais. J Ilmu Keperawatan. 2012;7:79-86.

11. Gitanjali N, Sreehari R. Progressive Relaxation as A Muti-Pronged Pyschotherapeutic Technique For Anxiety. Amrita J Med. 2014;10:1-44. 